\title{
Efektivitas Komunikasi Massa Pasangan Jokowi-Ahok Sebelum dan Sesudah Pilkada DKI Jakarta Tahun 2012
}

\author{
Intan Rawit Sapanti \\ Universitas Ahmad Dahlan, Yogyakarta \\ Intanrawit.sapanti@idlitera.uad.ac.id \\ *corresponding author
}

Keywords:

Mass Communication, Local

Elections, Jokowi-Ahok

\section{Kata Kunci:}

Komunikasi Massa, Pilkada, Jokowi-Ahok

\begin{abstract}
The aim of this research is to find out the efectivity and also the variety of mass communication used by Jokowi-Ahok in DKI Jakarta Local Elections 2012. The method used on this research is quantitative which used numbering in data in the form of scoring/grade, raking, frequency, and analyzed using the statistics to answer the questions or research hyphotesis in a spesific way and to make a prediction that certain variable influence other variable. The result of this research show that on DKI Jakarta local elections 2012, Jokowi-Ahok had succed to influence their sympathizer and supporter from three aspects; cognitive, afective, and behavioral aspects.
\end{abstract}

\begin{abstract}
ABSTRAK
Penelitian ini bertujuan untuk mengetahui efektivitas komunikasi massa yang digunakan pasangan Jokowi-Ahok dalam Pilkada Jakarta 2012. Khususnya pada jenis efek komunikasi massa yang muncul dari pasangan Jokowi Ahok pada Pilkada DKI Jakarta tahun 2012. Metode yang digunakan dalam penelitian ini menggunakan pendekatan kualitatif, yakni penelitian yang bekerja dengan angka, datanya berwujud bilangan (skor atau nilai, peringkat, frekuensi), dan dianalisis dengan menggunakan statistik untuk menjawab pertanyaan atau hipotesis penelitian yang sifatnya spesifik dan untuk melakukan prediksi bahwa suatu variabel tertentu mempengaruhi variabel yang lain. Hasil dari penelitian ini dapat disimpulkan bahwa pada Pilkada DKI Jakarta 2012, pasangan Jokowi-Ahok dalam komunikasi massanya berhasil mempengaruhi simpatisan dan pendukungnya dalam tiga aspek yaitu; aspek kognitif, aspek afektif, dan behavioral.
\end{abstract}

Copyright (C) 2019 Channel Jurnal Komunikasi. All right reserved.

\section{PENDAHULUAN}

Pemilihan Gubernur (Pilgub) DKI Jakarta telah berlangsung beberapa saat yang lalu. Hasil Pilgub DKI Jakarta menciptakan sebuah kejutan bagi semua pihak. Kejutan itu bukan hanya bagi para politikus tetapi juga para akademisi, pengamat politik dan bahkan bagi rakyat jelata. Dengan perolehan 53,82 persen suara dari total 4.592 .945 pemilih (sumber: KPUD DKI Jakarta), Joko Widodo-Basuki T Purnama (Jokowi-Ahok) mampu menggusur nama-nama besar seperti incumbent Fauzi Bowo dan Hidayat Nurwahid (mantan Ketua MPR RI).

Peristiwa kemenangan politik Jokowi-Ahok pada Pilgub DKI Jakarta diduga merupakan sebuah keberhasilan komunikasi massa yang tercipta karena adanya dukungan pemberitaan media massa yang massive baik melalui media cetak, elektronik maupun media internet yang mengakomodasi informasi bagi masyarakat yang terpelajar. Komunikasi massa yang tersampaikan melalui berbagai media massa, idealnya adalah informasi yang bersifat objektif. Masyarakatlah yang kemudian menginterpretasikannya, apakah informasi tersebut diasumsikan sebagai pencitraan positif, ataupun diasumsikan sebagai pencitraan negatif bagi calon pasangan gubernur/kepala daerah tertentu untuk kepentingan kampanye politiknya. 
Banyak fenomena politisi yang gagal menempatkan diri pada posisi yang positif dalam sebuah komunikasi massa yang mengiringi proses Pilgub maupun Pilkada di daerah-daerah di seluruh Indonesia. Para calon pemimpin daerah yang notabene berlatar belakang sebagai public figure ataupun "artis nasional" sekalipun, acap kali menemui kegagalan dalam Pilgub maupun Pilkada di daerah. Namun kita menemukan anomali pada pasangan Jokowi Ahok yang dianggap (diduga) berhasil menempatkan dirinya pada posisi yang menguntungkan/positif dalam komunikasi massa pada Pilkada DKI Jakarta tahun 2012 ini. Politik pencitraan Jokowi memang tergolong unik bahkan bisa disebut sebagai terobosan baru dalam strategi pencitraan konvensional di Indonesia. la tidak menggunakan strategi baliho, spanduk, dan billboard ataupun pembagian sembako seperti calon-calon lainnya. la lebih mengandalkan pencitraan aktivitas keseharian yang dimuat oleh berbagai media.

Dugaan atau anggapan keberhasilan/efektifitas komunikasi massa Jokowi-Ahok dalam Pilgub DKI Jakarta inilah yang kemudian menjadi landasan dilakukannya penelitian ini. Efek komunikasi massa yang akan secara lebih detail dibahas secara teoritis pada bab landasan teori dalam paper ini, mencakup tiga jenis efek komunikasi massa: (a) efek komunikasi massa kognitif, yaitu peristiwa/informasi yang disampaikan melalui media massa yang mampu membuat masyarakat dalam kondisi "mengetahui" atau "memahami" sebuah informasi dari kondisi sebelumnya dimana mereka "belum tahu" atau "belum paham" akan sebuah peristiwa/informasi yang disampaikan melalui media massa, (b) efek komunikasi massa affektif, yaitu peristiwa/informasi yang disampaikan melalui media massa yang mampu membuat masyarakat ber-empati, iba, senang, sedih, ataupun kondisi-kondisi emosional masyarakat, dan (c) efek komunikasi massa behavioral, merupakan peristiwa/informasi yang disampaikan melalui media massa yang mampu membuat khalayak menduplikasi dan membuat masyarakat tersebut melakukan sesuatu sebagai dampak dari apa yang disampaikan karena peristiwa/sosok yang diinformasikan tersebut. Dalam penelitian ini, tim peneliti mendapatkan data penelitiannya melalui kuesioner yang mengandung butir-butir pertanyaan yang mengimplikasikan jenis kualitas efek komunikasi massa pada pasangan Gubernur Jokowi Ahok, metode penelitian ini dibahas lebih lanjut pada bab metodologi penelitian.

Tim peneliti berharap, hasil dari penelitian ini mampu membuktikan secara akademis dugaan atau anggapan tentang keberhasilan/efektifitas komunikasi massa pasangan Gubernur DKI Jakarta Jokowi-Ahok pada periode waktu sebelum sampai setelah Pilgub DKI Jakarta berlangsung, sebagaimana dibahas pada bab pembahasan dalam paper penelitian ini.

\section{METODE PENELITIAN}

Penelitian ini menggunakan pendekatan kuanttatif, yakni penelitian yang bekerja dengan angka, datanya berwujud bilangan (skor atau nilai, peringkat, frekuensi), dan dianalisis dengan menggunakan statistik untuk menjawab pertanyaan atau hipotesis penelitian yang sifatnya spesifik dan untuk melakukan prediksi bahwa suatu variabel tertentu mempengaruhi variabel yang lain (Creswell 2002). Jawaban responden yang akan dihimpun oleh peneliti berupa data yang berwujud angka yang menjadi tolok ukur efektivitas variabel tertentu. Penelitian kuantitatif secara tipikal dikaitkan dengan proses induksi enumeratif, yaitu menarik kesimpulan bedasar angka dan melakukan abstraksi berdasar generalisasi (Alsa 12-13).

\section{A. Metode Pengumpulan Data}

Rancangan survei merupakan salah satu prosedur dalam penelitian kuantitatif yang digunakan untuk meneliti kecenderungan perilaku individu dalam populasi yang besar. Peneliti melaksanakan survei atau memberikan angket pada satu sampel untuk mendeskripsikan sikap, opini, perilaku atau karakteristik responden. Dari hasil survei ini peneliti membuat klaim tentang kecenderungan yang ada dalam populasi (Alsa 2003: 20-21). Dengan demikian, penelitian ini menggunakan metode kuesioner (angket). Kuesioner adalah suatu daftar yang berisikan rangkaian pertanyaan mengenai sesuatu masalah atau bidang yang akan diteliti. Untuk memperoleh data, angket disebarkan kepada responden (Narbuko dan Achmadi 2003: 76).

Dalam penelitian ini peneliti tertarik untuk mendeskripsikan efektivitas komunikasi massa pasangan Jokowi-Ahok sebelum dan setelah Pilkada DKI Jakarta tahun 2012. Pertanyaan-pertanyaan dalam angket bersifat terbuka sehingga jawaban responden merupakan respon tentang masalah yang ditanyakan. Fokus pertanyaan dalam angket bertujuan untuk menggali efektivitas komunikasi massa Jokowi-Ahok terhadap masyarakat luas. Untuk mempermudah pengukuran efektivitas komunikasi massa tersebut, peneliti mengelompokkan pertanyaan-pertanyaan ke dalam tiga indikator yang terlihat dalam tabel di bawah ini.

Tabel 1. Indikator Kuesioner

\begin{tabular}{|l|c|c|}
\hline \multicolumn{1}{|c|}{ Indikator } & Nomor & Jumlah Pertanyaan \\
\hline Efek Kognitif & $3,2,1$ & 3 \\
\hline Efek Afektif & $8,5,4$ & 3 \\
\hline Efek Behavioral & 7,6 & 2 \\
\hline & Jumlah Keseluruhan & 8 \\
\hline
\end{tabular}


Angket yang dibagikan kepada responden bertipe pilihan sekaligus isian. Angket tipe pilihan yang harus dijawab oleh responden dengan cara memilih satu jawaban yang tersedia, sedangkan angket tipe isian harus dijawab oleh responden dengan mengisi format titik pada tiap pertanyaan. Angket yang digunakan oleh peneliti terdiri dari delapan pertanyaan, masing-masing tujuh nomor memiliki pilihan jawaban pilihan ganda dan sebuah nomor merupakan tipe isian.

Bagian awal lembaran kuesioner berisi: (1) identitas responden, meliputi: nama, usia, dan pekerjaan; (2) petunjuk pengisian kuesioner, yaitu: (a) pada soal nomor 1-7, pilihlah satu jawaban yang Anda anggap paling benar dengan memberikan tanda silang pada (a), (b), (c), atau (d); (b) pada soal nomor 8, jawablah pertanyaan dengan jelas.

Angket langsung dikirimkan kepada responden untuk dijawab. Responden dipilih secara acak dengan syarat responden adalah WNI yang berusia di atas 18 tahun, baik warga DKI Jakarta yang memiliki hak pilih maupun warga di luar wilayah DKI Jakarta.

\section{B. Analisis data}

Tahap yang dilalui setelah angket dikembalikan oleh responden adalah analisis data. Langkah-langkah yang dilakukan adalah sebagai berikut (Narbuko dan Achmadi 1993: 82-83).

1. Mengecek kelengkapan jawaban yang diterima, keterbacaan tulisan, kejelasan makna jawaban, kesesuaian jawaban, relevansi jawaban, dan keseragaman satuan data.

2. Mentabulasikan hasil-hasil jawaban ke dalam daftar tabulasi dan memisahkan jawaban yang kurang lengkap.

3. Mempertimbangkan validitas jawaban-jawaban yang kurang lengkap.

4. Memastikan data yang dimasukkan sudah komplet dan persiapan analisis (tabulasi) telah cukup baik dan benar.

5. Menganalisis data dengan analisis kuantitatif agar lebih mendalam dan konkret atau dengan analisis kualitatif bila kajiannya sederhana.

\section{HASIL DAN ANALISIS}

\section{A. Efektivitas Komunikasi Massa Pasangan Jokowi-Ahok terhadap aspek Kognitif}

Efek kognitif adalah akibat yang timbul pada diri komunikan yang sifatnya informatif bagi dirinya. Dalam efek kognitif ini biasanya membahas tentang bagaimana komunikasi massa dapat membantu khalayak dalam mempelajari informasi yang bermanfaat dan dapat mengembangkan keterampilan kognitif.

Dalam kuesioner penelitian ini aspek kognitif diwakili oleh pertanyaan no 1, 2 dan 3 yang meliputi pertanyaan seputar pengetahuan responden tentang sosok atau identitas serta kebijakan pasangan Jokowi-Ahok.

Di bawah ini adalah tabel hasil perolehan data kuesioner untuk pertanyaan no 1, 2 dan 3.

Tabel 2. Perolehan Data Kuesioner

\begin{tabular}{|c|c|c|c|c|}
\hline No. & $\begin{array}{c}\text { Pilihan } \\
\text { Jawaban }\end{array}$ & No.1 & No.2 & No.3 \\
\hline 1 & Jawaban A & 5 & 8 & 35 \\
\hline 2 & Jawaban B & 11 & 17 & 2 \\
\hline 3 & Jawaban C & 2 & - & 2 \\
\hline 4 & Jawaban D & 31 & 18 & 7 \\
\hline \multicolumn{2}{|l}{ Total } & 42 & 42 & 42 \\
\hline
\end{tabular}

Dari pertanyaan no 1 tentang sumber informasi darimana responden mengetahui dan mengenal sosok JokowiAhok, jawaban terbanyak (31 responden) adalah melalui media elektronik dan sebanyak 11 responden memilih media cetak, dan 5 responden memilih media internet. Pernyataan no 2 adalah mengenai Jargon Politik yang diusung pasangan Jokowi-Ahok dan mayoritas responden (18 responden) menjawab dengan pilihan D yaitu tidak tahu. Pertanyaan no 3 tentang seberapa jauh responden mengetahui kebijakan pasangan Jokowi-Ahok dan mayoritas responden (35 orang) memberi jawaban A yaitu kartu sehat.

Melalui hasil kuesioner di atas, maka dapat kita tarik kesimpulan bahwa komunikasi massa yang dilakukan Pasangan Jokowi-Ahok berhasil mempengaruhi aspek kognitif responden yang mewakili para pemilih. Masyarakat dapat dengan mudah mendapat informasi dari berbagai macam media, diantaranya yaitu media elektronik (televisi, radio), media cetak dan internet. Keberhasilan Jokowi-Ahok dalam menyampaikan informasi yang terkait dengan pemenuhan aspek kognitif para pemilih melalui berbagai media massa secara otomatis juga memberi kontribusi terhadap pembentukan citra pasangan tersebut. Citra terbentuk berdasarkan informasi yang kita terima.

Media massa bekerja untuk menyampaikan informasi. Bagi khalayak, informasi dapat membentuk, mempertahankan atau meredefinisikan citra. Berbekal persepsi masyarakat soal kepemimpinan Jokowi di Solo yang dinilai berhasil selama menjabat sebagai walikota hingga dua periode, ia dinilai punya modal dalam kualitas personal untuk bersaing dengan kandidat lain. Popularitasnya di lingkup nasional, baik karena kebijakannya yang populis, maupun karena sosoknya, 
menambah kepercayaan masyarakat untuk memilih Jokowi-Ahok untuk memilih Jakarta.

Menurut McLuhan dalam Griffin (2006), media massa adalah perpanjangan alat indera (sense extention theory, teori perpanjangan alat indera). Dengan media massa khalayak memperoleh informasi tentang benda, orang atau tempat yang belum pernah dilihat atau belum pernah dikunjungi secara langsung. Realitas yang ditampilkan oleh media massa adalah realitas yang sudah diseleksi. Khalayak cenderung memperoleh informasi tersebut semata-mata berdasarkan pada apa yang dilaporkan media massa. Akhirnya khalayak membentuk citra tentang lingkungan sosial berdasarkan realita kedua yang ditampilkan media massa.

Karena media massa melaporkan dunia nyata secara selektif, maka sudah tentu media massa akan mempengaruhi pembentukan citra tentang lingkungan sosial yang bias dan timpang. Oleh karena itu muncullah apa yang disebut stereotip, yaitu gambaran umum tentang individu, kelompok, profesi, atau masyarakat yang tidak berubah-ubah.

Pada kasus Jokowi-Ahok realita di atas digambarkan dengan banyaknya aksi dukungan terhadap pasangan tersebut yang disampaikan dalam beragam versi, contohnya dengan banyak ditemukannya video di Youtube mulai dari versi serius ala talkshow hingga gubahan aneka lagu populer berbagai versi dalam dan luar negeri, yang diadopsi dan diubah liriknya menjadi lagu dukungan bagi pasangan tersebut. Diantaranya tarian kuda dari Korea, atau yang sangat dikenal dengan Gangnam Style, tampil di Youtube dengan kemeja kotak-kotak. Lagu Warteg Boys, Okelah kalau begitu, yang sejak awal diubah liriknya untuk mendukung Foke-Nara dibuatkan cover versionnya oleh pihak pendukung Jokowi-Ahok menjadi lagu pendukung pasangan tersebut. '

\section{B. Efektifitas Komunikasi Massa Pasangan Jokowi-Ahok terhadap aspek Afektif}

Efek ini kadarnya lebih tinggi daripada efek kognitif. Tujuan dari komunikasi massa bukan hanya sekedar memberitahu kepada khalayak agar menjadi tahu tentang sesuatu, tetapi lebih dari itu, setelah mengetahui informasi yang diterimanya, khalayak diharapkan dapat merasakannya. Adapun semua sikap bersumber pada organisasi kognitif, informasi dan pengetahuan yang dimiliki khalayak. Sikap pada seseorang atau sesuatu tergantung pada citra khalayak tentang orang atau obyek tersebut. Sebagai contoh, setelah khalayak mendengar atau membaca informasi tentang pasangan Jokowi-Ahok akan muncul perasaan senang, simpati, jengkel, iba, kasihan ataupun marah.

Adapun efek komunikasi massa yang dilakukan oleh Pasangan Jokowi Ahok terhadap aspek afektif diwakili oleh pertanyaan no. 4,5, dan 8. Pertanyaan no.4 menanyakan kepada responden ketika beredarnya isu sara (black campaign) yang menyudutkan pasangan Jokowi-Ahok, perasaan apakah yang muncul dalam diri responden. Sebagian besar responden sejumlah 25 orang memilih opsi C ( biasa-biasa saja), 22 orang memilih opsi A (empati). Pertanyaan no.5 menanyakan kepada responden tentang perasaan apa yang mungkin muncul ketika Wakil Gubernur Ahok memarahi staffnya karena lalai melaksanakan tugasnya sebagai notulis, sebanyak 29 orang bersimpati dan setuju dengan tindakan tersebut. Sebanyak 14 orang memilih jawaban C (biasa-biasa) saja. Pertanyaan no. 8 adalah tentang deskripsi responden tentang pasangan Jokowi-Ahok dalam 5 kata, jawaban terbanyak adalah merakyat, tegas, disiplin, sederhana dan berwibawa.

Komunikasi massa yang dilakukan pasangan Jokowi-Ahok pada aspek afektif memberikan efek dukungan real dari para simpatisan dan pendukungnya yang sangat kental. Militansi yang terbentuk bermuara pada satu semangat, Jokowi-Ahok diharapkan menang dengan kesadaran bahwa merekalah yang akan menjadi roda gulir menuju kemenangan tersebut.

Media massa berperan penting dalam mempengaruhi aspek afektif dalam bentuk rangsangan emosional. Beberapa faktor yang mempengaruhi intensitas rangsangan emosional pesan media massa adalah :

\section{Suasana emosional.}

Respon khalayak terhadap informasi yang disampaikan melalui media massa akan dipengaruhi oleh suasana emosional khalayak. Sebagai contoh dalam kasus Roma Irama melontarkan isu sara dalam khotbahnya yang menyatakan bahwa Jokowi-Ahok tidak pantas dipilih karena latar belakang mereka yang berbeda agama dan etnis mengundang reaksi banyaknya simpati serta dukungan moril bagi pasangan tersebut.

\section{Skema kognitif}

Skema kognitif merupakan naskah yang ada dalam pikiran khalayak yang menjelaskan tentang alur peristiwa. Khalayak tahu bahwa Jakarta membutuhkan perubahan dalam segala aspek, dan pasangan Jokowi-Ahok terlihat sangat menjanjikan untuk dapat merealisasikan harapan tersebut. Sehingga para pendukung dan simpatisan mempunya gambaran bahwa pasangan tersebut akan menang pada Pilkada DKI 2012.

\section{Situasi Terpaan (setting of exposure).}

Masyarakat Jakarta sudah begitu putus asanya terhadap berbagai macam masalah yang menerpa Jakarta mulai dari masalah kemacetan, banjir, akses kesehatan dan pendidikan yang layak dan dengan kemunculan pasangan Jokowi-Ahok yang dipandang mengusung harapan-harapan baru melalui kebijakan yang lebih pro-rakyat membuat masyarakat Jakarta merasa pasangan tersebut adalah pasangan yang paling tepat untuk memimpin Jakarta. 


\section{Faktor predisposisi individual}

Faktor ini menunjukkan sejauh mana orang merasa terlibat dengan tokoh yang ditampilkan dalam media massa. Pasangan Jokowi - Ahok dinilai lebih berhasil dalam mendapatkan simpati dari masyarakat Jakarta dari berbagai kalangan, terutama kalangan menengah bawah karena bahasa yang mereka gunakan dianggap sebagai bahasa seseorang kepada temannya. Sebagai contoh adalah pada saat Jokowi tidak segan untuk menyapa para supir taksi di bandara dan pada saat ia masuk keluar gang sempit yang kumuh untuk melakukan dialog dengan masyarakat. Faktor ini menunjukkan apa yang dirasakan tokoh. Oleh karena itu, ketika tokoh (disebut identikan) itu kalah, ia juga kecewa. Ketika identifikan itu berhasil, ia gembira. Jadi pada saat pasangan Jokowi-Ahok berhasil mengungguli pasangan Foke-Nara, semua simpatisan dan pendukungnya juga merasakan kegembiraan yang luar biasa

\section{Efektivitas Komunikasi Massa Pasangan Jokowi-Ahok terhadap Aspek Behavioral}

Efek behavioral merupakan akibat yang timbul pada diri khalayak dalam bentuk perilaku, tindakan atau kegiatan. Efek yang dihasilkan dari media massa tidak selalu sama, ada yang berhasil merubah khalayak menjadi lebih baik namun ada pula yang mengakibatkan kegagalan yang berakhir pada tindakan buruk.

Bandura (1977) menjelaskan proses belajar sosial dalam empat tahapan proses; proses perhatian, proses pengingatan (retention), proses reproduksi motoris, dan proses motivasional. Permulaan proses belajar ialah munculnya peristiwa yang dapat diamati

Bandura (1977) menjelaskan proses belajar sosial dalam empat tahapan proses: proses perhatian, proses pengingatan (retention), proses reproduksi motoris, dan proses motivasional. Permulaan proses belajar ialah munculnya peristiwa yang dapat diamati secara langsung atau tidak langsung oleh seseorang. Peristiwa ini dapat berupa tindakan tertentu (misalnya menolong orang tenggelam) atau gambaran pola pemikiran, yang disebut Bandura sebagai "abstract modelling" (misalnya sikap, nilai, atau persepsi realitas sosial). Khalayak mengamati peristiwa tersebut dari orangorang di sekitarnya. Bila peristiwa itu sudah diamati, terjadilah tahap pertama belajar sosial: perhatian. Khalayak baru dapat mempelajari sesuatu bila khalayak memperhatikannya. Setiap saat khalayak menyaksikan berbagai peristiwa yang dapat diteladani, namun tidak semua peristiwa itu diperhatikan. Perhatian saja tidak cukup menghasilkan efek prososial. Khalayak harus sanggup menyimpan hasil pengamatannya dalam benak-benaknya dan memanggilnya kembali ketika mereka akan bertindak sesuai dengan teladan yang diberikan. Untuk mengingat, peristiwa yang diamati harus direkam dalam bentuk imaginal dan verbal. Yang pertama disebut visual imagination, yaitu gambaran mental tentang peristiwa yang diamati dan menyimpan gambaran itu pada memorinya. Yang kedua menunjukkan representasi dalam bentuk bahasa. Menurut Bandura, agar peristiwa itu dapat diteladani, khalayak bukan saja harus merekamnya dalam memori, tetapi juga harus membayangkan secara mental bagaimana khalayak dapat menjalankan tindakan yang diteladani. Memvisualisasikan dirinya sedang melakukan sesuatu disebut sabagai "rehearsal".

Selanjutnya, proses reproduksi artinya menghasilkan kembali perilaku atau tindakan yang khalayak amati. Tetapi apakah khalayak betul-betul melaksanakan perilaku teladan itu bergantung pada motivasi? Motivasi bergantung ada peneguhan. Ada tiga macam peneguhan yang mendorong khalayak bertindak: peneguhan eksternal, peneguhan gantian (vicarious reinforcement), dan peneguhan diri (self reinforcement). Pelajaran bahasa Indonesia yang baik dan benar telah khalayak simpan dalam memorinya. Khalayak bermaksud mempraktekkannya dalam percakapan sehari-hari. Khalayak akan melakukan hanya apabila orang lain tidak akan mencemoohkannya atau bila khalayak yakin orang lain akan menghargai tindakannya. Ini yang disebut peneguhan eksternal. Jadi, kampanye bahasa Indoensia dalam TVRI dan surat kabar berhasil, bila ada iklim yang mendorong penggunaan bahasa Indoensia yang baik dan benar.

Khalayak juga akan terdorong melakukan perilaku teladan baik apabila melihat orang lain yang berbuat sama mendapat ganjaran karena perbuatannya. Secara teoritis, agak sukar orang meniru bahasa Indonesia yang benar bila pejabat-pejabat yang memiliki reputasi tinggi justru berbahasa Indonesia yang salah. Khalayak memerlukan peneguhan gantian. Walaupun khalayak tidak mendapat ganjaran (pujian, penghargaan, status, dan sebagainya), tetapi melihat orang lain mendapat ganjaran karena perbuatan yang ingin diteladani membantu terjadinya reproduksi motor. Akhirnya tindakan teladan akan khalayak lakukan bila dirinya sendiri mendorong tindakan itu. Dorongan dari diri sendiri itu mungkin timbul dari perasaan puas, senang, atau dipenuhinya citra diri yang ideal. Khalayak akan mengikuti anjuran berbahasa Indonesia yang benar bila diyakini bahwa dengan cara itu dapat memberikan kontribusi bagi kelestarian bahasa Indonesia.

Pada kuesioner penelitian ini, efektivitas komunikasi Massa pasangan Jokowi-Ahok terhadap aspek behavioral tercermin dalam pertanyaan no. 7 dan no. 8. Pertanyaan no.7 menanyakan kepada responden seandainya responden adalah seorang warga DKI yang memiliki hak pilih suara dalam Pilkada DKI Jakarta, sejumlah 40 responden dari 46 responden memilih jawaban $\mathrm{A}$ (Ya).

Berdasarkan analisa hasil kuestioner diatas maka dapat diambil diambil kesimpulan bahwa media massa yaitu radio, televisi, atau internet telah berhasil menunjukkan manfaat yang nyata dan membuat para responden setelah mengetahui pasangan Jokowi-Ahok, kemudian merasakan perasaan emosional kemudian memilihnya sebagai pasangan Gubernur dan Calon Gubernur DKI Jakarta. 


\section{KESIMPULAN}

Dari hasil penelitian yang telah dilakukan, terdapat beberapa simpulan dari hasil analisis tersebut, yaitu :

Berdasarkan analisa yang telah dipaparkan penulis pada bagian pembahasan mengenai efektivitas komunikasi massa yang dilakukan oleh pasangan Jokowi-Ahok sebelum dan sesudah Pilkada DKI 2012, dapat disimpulkan bahwa pada Pilkada DKI Jakarta 2012, pasangan Jokowi-Ahok dalam komunikasi massanya berhasil mempengaruhi simpatisan dan pendukungnya dalam tiga aspek yaitu; aspek kognitif, aspek afektif, dan behavioral. Aspek pertama yaitu aspek Pasangan Jokowi-Ahok berhasil secara efektif mempengaruhi aspek kognitif responden yang mewakili para pemilih. Masyarakat dapat dengan mudah mengakses informasi dari berbagai macam media, diantaranya yaitu media elektronik (televisi, radio), media cetak dan internet terkait pasangan tersebut. Aspek kedua yaitu aspek afektif memberikan efek dukungan real dari para simpatisan dan pendukungnya yang sangat kental. Militansi yang terbentuk bermuara pada satu semangat, Jokowi-Ahok diharapkan menang dengan kesadaran bahwa merekalah yang akan menjadi roda gulir menuju kemenangan tersebut. Aspek ketiga yaitu aspek behavioral dapat diambil diambil kesimpulan bahwa media massa yaitu radio, televisi, atau internet telah berhasil menunjukkan manfaat yang nyata dan membuat para responden setelah mengetahui pasangan Jokowi-Ahok, kemudian merasakan perasaan emosional kemudian memilihnya sebagai pasangan Gubernur dan Calon Gubernur DKI Jakarta

\section{DAFTAR PUSTAKA}

Alsa, Asmadi. 2003. Pendekatan Kuantitatif dan Kualitatif serta Kombinasinya Dalam Penelitian Psikologi. Yogyakarta: Pustaka Pelajar.

Bandura, A. 1977. Social Learning Theory. Englewood Cliffs, New Jersey: Prentice-Hall

Griffin, E.M. 2006. First Look At Communication Theory . New York:McGraw-Hill.

Hermawan, A.S. 2012. Efektivitas Publikasi dan Pemasaran ala Jokowi-Ahok. Sindo

Jahi, A. 1988. Komunikasi Massa dan Pembangunan Pedesaan di Negara-negara Dunia Ketiga. Jakarta:PT.Gramedia

Karlinah, S. 1999. Komunikasi Massa. Jakarta: Penerbitan UT.

Narbuko, Cholid dan Abu Achmadi. 2003. Metodologi Penelitian. Jakarta: Bumi Aksara.

Rakhmat, J.2007. Psikologi Komunikasi (Edisi revisi). Bandung:PT. Remaja Rosdakarya

Ristian, Andre. 2012. Belajar dari Jokowi-Ahok. Bangkapos

Sosiawan, E.A. Psikologi Komunikasi. Www.edwias.com

Hendra Agus Setyawan. Strategi Komunikasi Politik Calon Gubernur Menjelang Pemilukada Sumatera Selatan 2008

Jurnal Ilmiah Dinamika Vol. 1 No. 1 Juni 2008 ISSN 1979 - 0899X

Intan Rawit Sapanti (Efektivitas Komunikasi Massa Pasangan Jokowi-Ahok Sebelum dan Sesudah Pilkada DKI Jakarta Tahun 2012) 